Journal of Language \& Translation 9-2

September 2008, 49-70

\title{
The Cultural Embeddedness of Legal Texts
}

\author{
Alenka Kocbek \\ University of Primorska
}

\begin{abstract}
The functionalist approaches in translation science lay great stress on the principle of cultural embeddedness of the source and the target languages and accordingly view translation as an intercultural transfer. In legal communication based on legal texts, communicative situations are directly affected by the legal systems of the source and target cultures. The legal system of one of the parties involved or, more rarely, a supranational legal system, is generally adopted as the communication framework and thus defines the language to be used. The translatability of legal texts, however, directly depends on the relatedness of the legal systems underlying the translation. The communicating parties therefore need to be well acquainted with the legal system(s) involved. This is especially the case when using English as the language of communication, as the Anglo-American legal system, based essentially on common law, differs substantially from continental law, to which most of European countries belong. The nonequivalence of many legal concepts and terms pertaining to these two systems thus has to be taken into consideration. In this paper, cases of non-equivalence will be illustrated with examples from the terminology used to define different types of system-bound legal professions and court structures, as well as with specific terms referring to particular areas of law, such as company law.
\end{abstract}


Keywords: legal translation, lingua franca, cultural embeddedness, common law, continental law, memes

\section{Introduction}

In intercultural contacts language skills represent one of the fundamental competences enabling communication between participants belonging to different nations and hence different cultures to take place. Intercultural communication is conducted in either the language of one of the parties involved or in a third, neutral language, serving as lingua franca. Thus, language skills as a means of intercultural communication always imply a certain extent of implicit or explicit translating.

The functionalist approaches in translation science and most of all the Skopos theory by the German scholar J. H. Vermeer lay great stress on the importance of a clearly defined purpose (i.e. skopos) of a translation, the necessity for a precise and complete translation brief/commission, the assertion of the role of the translator as intercultural expert, and the application of the principle of cultural embeddedness of the source and target texts. Accordingly, they view translation as an intercultural transfer, which inevitably entails taking into account intercultural differences. While in a multicultural environment communicative situations are affected by different aspects of the cultures involved, in international legal communication the legal systems of the source and target cultures undoubtedly require particular consideration. As a rule, the legal system of one of the parties involved or, more rarely, a supranational legal system, are adopted as the communication framework. 


\section{The Functionalist Approach to Cultural Embeddedness}

Translation as a communicative activity pursues a certain purpose or goal which the German scholar H. Vermeer terms skopos (Greek for aim or purpose). This purpose determines the translation method and strategies to be used in order to produce a functionally adequate translation. Moreover, translation takes place in concrete, definable situations which are limited in time and space and involve members of different cultures. These situations can be said to be embedded in given cultures, which, in turn, condition the situations. Language is thus an essential means of communication, but it has to be used in the context of the corresponding culture. In Translation Studies Bassnett illustrates the interrelatedness and essential interdependence of language and culture by means of the following metaphor:

No language can exist unless it is steeped in the context of culture; and no culture can exist which does not have at its center, the structure of natural language. Language, then, is the heart within the body of culture, and it is the interaction between the two that results in the continuation of lifeenergy. In the same way that the surgeon, operating on the heart, cannot neglect the body that surrounds it, so the translator treats the text in isolation from the culture at his peril (Bassnett 1991: 14).

There is little doubt that language and culture are fundamentally interlinked, for it is the culture underlying a specific language that defines the codes for interpreting messages conveyed by using this language through the specific norms and conventions governing the culture in the variety of its contexts. In the case of legal language, the "body of culture" coincides with all aspects of the legal system 
governing and defining a given culture. What Bassnett's metaphor of language as the "heart within the body of culture" implies is, however, the fact that a language used as a lingua franca, i.e. having no specific cultural foundation, is somehow impoverished, as it is deprived of its wider cultural dimensions, of the richness and variety of its cultural background. Drawing on the metaphor of the language as a heart within the body we may argue that a lingua franca undoubtedly lacks a deeper connection to a specific cultural basis. And, to further develop Bassnett's metaphor, there is no living body surrounding it and supplying the necessary life-energy, but rather a sterile, artificial environment. Such a language is somehow a mechanical heart, which can serve as a surrogate but can never substitute the real organ and when it is used in communication, the communicating parties should take into account its limits, i.e. the fact that it may prove inadequate to express and convey concepts which have a strong cultural connotation.

Besides a good command of the language, participants in intercultural communication therefore need to have a thorough knowledge of other aspects of the cultures involved, which are relevant to their communicative situation. Some of these aspects can be deduced from Vermeer's definition of culture as "the entire setting of norms and conventions an individual as a member of his society must know in order to be "like everybody" - or to be able to be different from everybody" (Vermeer 1987: 28).

Reiß points out that norms have a stronger prescriptive character (indicating what the members of a society have to do or are not allowed to do) and are as such obligatory, whereas the term convention indicates that a rule of behaviour has gradually been established by general consensus and thus indicates the recommended, expected forms of behaviour in a society. ${ }^{1}$ If we compare Vermeer's concept of culture viewed as a setting of norms

\footnotetext{
${ }^{1}$ Cf. Reiß \& Vermeer (1984: 178).
} 
and conventions to be followed by members of a society with Jenkins's statement that "law has the basic function in society of guiding human behaviour and regulating human relations " (Jenkins 1980: 103), we see that the norms, which according to Vermeer govern the conduct of the members of a society, are actually reflected in the body of rules considered as binding by these members, i.e. in the legal system of a society.

\section{The Relationship of Language and Law in Legal Communication}

In international legal communication, norms which directly affect communicative situations undoubtedly include the legal system(s) involved. In order to avoid communication problems participants in this communication must necessarily have a good knowledge of the legal systems of both the source and the target culture. As the legal systems of the parties involved directly condition communicative situations through the legal provisions and regulations applying to concrete legal transactions, the interactants have to agree which legal system will be adopted as the communication framework. Within this communication framework legal concepts have to be translated (culturally transferred) from one language/culture/legal system into another.

Gérard-René de Groot, Professor of Comparative and Private International Law at Maastricht University, the Netherlands, points out that the crucial issue to be taken into consideration when translating legal concepts is the fact that "The language of the law is very much a system-bound language, i.e. a language related to a specific legal system. Translators of legal terminology are obliged therefore to practice comparative law" (de Groot 1998: 21 ff.). Legal systems differ from one state to another, and so far no standardized international legal terminology has come into existence. 
Every state (sometimes even regions within a state) has developed independent legal terminologies, whereas a multilingual international legal terminology is only being created gradually within supranational legal systems, such as the law of the European Union, and is being introduced in single areas of the European law as they undergo harmonisation.

When translating from one legal system into another the differences existing between them have to be considered. Sandrini points out that the translatability of legal texts fundamentally and directly depends on the relatedness of the legal systems involved in the translation. ${ }^{2}$ Legal systems exist independently from the legal languages they use and are created through social and political circumstances. There is no direct correlation between legal language and legal systems. One legal system may use different legal languages (Canada, Switzerland, bilingual areas in Slovenia, Austria, Italy, Belgium, etc.), while one language area may be divided in different legal systems, as it is the case in the United Kingdom or in the US.

If the legal systems are analyzed as to their sources, their historical background, the extent of codification and the specific legal institutes applied within them, some legal families show a greater relatedness than others. The legal systems pertaining to the so-called civil (i.e. continental) law, which includes the Romanic, the German and the Nordic legal systems, are relatively related. They have common foundations in the Roman legal tradition and are characterized by codification wherein the most important rules and regulations are set out in written sources of law. In the case of the continental legal systems, a considerable closeness with respect to the legal concepts applied can be expected. On the other hand, the legal systems of other countries and cultures, derived from different traditions, are difficult to compare - such as the Far-Eastern, the

\footnotetext{
${ }^{2}$ Cf. Sandrini (1999: 17).
} 
Islamic, the Hindu, and finally, the so-called Anglo-American legal family, based on common law, equity and statute law. Within the Anglo-American legal family common law is the legal system in force in England, Wales and with some differences in the US, whereas Scotland and Ireland have substantially different legal systems related to continental law, similarly to the legal system of Louisiana, which has its foundations in the French law.

These differences certainly affect the translatability of terms from/into different legal languages, as there is no complete equivalence between the legal concepts. According to de Groot, the first stage in translating legal concepts involves studying the meaning of the source-language legal term to be translated. Then, after having compared the legal systems involved, a term with the same content must be sought in the target-language legal system, i.e. equivalents for the source-language legal terms have to be found in the target legal language. If no acceptable equivalents can be found due to non-relatedness of the legal systems, one of the following subsidiary solutions can be applied: using the source-language term in its original or transcribed version, using a paraphrase or creating a neologism, i.e. using a term in the target-language that does not form part of the existing target-language terminology, if necessary with an explanatory footnote. ${ }^{3}$

The level of equivalence of the terms depends on the extent of relatedness of the legal systems (and not of the languages) involved. The relatedness of languages may, in same cases, even cause the creation of so-called false friends, such as the German Direktor (i.e. an operative function in a company) versus the English director (member of the board of directors, i.e. a function which may correspond to a Vorstandsmitglied or a Aufsichtsratsmitglied). When deciding on the solution to be used, the context of the translation, its purpose (skopos) and the character of the text play an important role.

\footnotetext{
${ }^{3}$ Cf. de Groot (1998: 25).
} 
A wide range of skopoi is possible: from mere information on the source text for a receiver who does not speak the target language to a translation which will have the status of an authentic text parallel to the source-text, as it is the case with international contracts made in two or even more equivalent language versions.

These different purposes of translation are reflected in the type of translation to be produced. Nord classifies translation in two basic types: a documentary translation, i.e. a document in the target language of (certain aspects of) a communicative interaction in which a source-culture sender communicates with a source-culture audience via the source-text under source-culture conditions; or an instrumental translation which aims to produce in the target language an instrument for a new communicative interaction between the source culture sender and the target language audience by using (certain aspects of) the source text as a model (Nord 1997: 47). For translation in legal settings this classification needs to be further elaborated. Cao thus classifies legal translation into three categories: translation for normative purposes, translation for informative purposes and translation for general legal or judicial purposes (2007: 10-12). Legal translation for normative purposes actually corresponds to Nord's instrumental translation, as it implies producing translations of domestic laws and international legal instruments in bilingual and multilingual jurisdictions, where the source and the target text have equal legal force. This kind of texts are often drafted in one language version and then translated into another language or languages, but the translation is nonetheless considered an authentic legal instrument and is equally binding as the source text. Examples of such translations are legal texts translated within bilingual/multilingual legislations (such as Switzerland, bilingual areas of Slovenia, Italy, Belgium, etc.), as well as the multilingual legal instruments of the UN and the EU, but also translations of private documents, such as contracts, which are made in two or more equally authentic language versions, all legally 
binding. Following Cao's classification, Nord's category of documentary translation needs to be subdivided into two further subcategories. The first is the legal translation for informative purposes, which has constative or descriptive functions and includes translations of different categories of legal texts (statutes, court decisions, scholarly texts), produced in order to provide information (in the form of a document) to target culture receivers, whereby the translations only have informative value and no legal force. Examples of such translations are often found in monolingual jurisdictions, where texts originating from other jurisdictions are translated in order to serve as a source of information on such jurisdictions (e.g., common law texts translated for continental legal experts or students for study purposes). The second subcategory is the translation for general or judicial purposes, where original source language texts are translated to be used in court proceedings as part of documentary evidence. These translations have an informative, as well as descriptive function and may include, apart from legal documents (pleadings, statements of claim, contracts, etc.), ordinary texts such as business or personal correspondence, witness statements and expert reports, etc., which are often not written in legal language by legal professionals, but enter the sphere of legal translation due to the special requirements of legal communication. These translations are meant to be used by parties in proceedings who do not speak the language used in court or by lawyers and/or court officials who need to access the original documents written in a language different from the one used in court.

Experienced translators will usually be able to establish which kind of translation is required in a given legal setting, i.e. identify the skopos, while the relevant information may also be supplied in the translation brief. According to the Skopos theory, the translation brief, i.e. commission can contribute considerably to the quality and functionality of the translation by providing the translator with explicit or implicit information about the intended 
target-text functions, addressees, the prospective time, place and motive of production and reception of the text (Nord 1997: 137). In the case of legal translation this information should also indicate the legal system to be observed as communication framework.

\section{English as Lingua Franca in Legal Communication}

Irrespective of their cultural backgrounds and origins, participants in international legal communication nowadays often choose English as the language of communication. The widespread use of English as a lingua franca is closely connected with its rise as a world language (Crystal 1997: 8-10). In the last century English has undoubtedly acquired the status of a "global" language - a situation that was predicted by Sapir as early as in 1931 (Sapir 1931: 66). On the other hand, due to its worldwide expansion and its status of a world language, English is nowadays increasingly used as a lingua franca in communication between non-native speakers. Van Essen (2002: 13) points out that English as a lingua franca is mostly used not only to socialize with native-speakers, but also as a requirement to become a member of an international community of experts and to communicate with other members of such a community (e.g. lawyers and law experts, business people, scientists, etc.) in the language (i.e. register) of that community about topics of common concern. The majority of such communicative interactions worldwide occur between non-native speakers of English whose cultural background is neither English nor American and for whom traditional cultural knowledge regarding the Anglo-American culture may prove utterly useless. On the other hand, these speakers necessitate a solid knowledge of specific aspects of the cultures involved in the communication, which are relevant to their interaction (e.g. the legal systems in the case of legal communication). 
As van Essen points out (2002: 14) there have been attempts to establish common standards as far as the linguistic aspects (pronunciation, grammar, vocabulary) of the lingua franca are concerned, such as for example the project of English as a lingua franca for Europe, also known by the abbreviation ELFE (or "EuroEnglish”, cf. Labrie and Quell 1997, Jenkins and Seidlhofer 2001), promoted within the European Union by some linguistic experts, which aims to standardize the use of the English language in the European Union.

The above mentioned standards covering the use of English as lingua franca, however, mostly take into account its linguistic dimensions. What may prove problematic are interactions conducted in English as lingua franca, in which cultural elements are referred to which are part of the specific socio-cultural environments of the interactants but alien to or non-existing in the Anglo-American culture, but still have to be conveyed by using English. While it may not be easy to develop linguistic standards for English as a lingua franca, it seems almost impossible to establish a common cultural basis to which to refer in such interactions. This is especially the case with aspects of culture, which are as precisely defined as the legal system, and due to their extremely sensitive nature demand an utterly precise and non-ambiguous use of the language. Presently, English is the commonly adopted lingua franca in international legal communication. At the same time this type of communication refers to a very precisely defined communication framework represented by the legal system(s) underlying the communicative situations, thus in this communication the principle of the cultural embeddedness of a language, i.e. adapting the language to the corresponding culture, has to be applied very carefully. Using the English language by consistently linking it to the Anglo-American legal system in communicative situations, in which participants originating from cultures/legal systems belonging to continental law interact, potentially implies the risk of introducing in the 
communication legal concepts which are alien to the cultures of the participants in the communication and may as such prejudice the legal security of the transactions. Unfortunately, not many dictionaries provide sufficient information to make the user aware of these potential problems/pitfalls.

\section{The Dichotomy Continental versus Common Law and its Impact on Legal Language}

In comparative law, the dichotomy civil (i.e. continental) versus common law (case-law), which is not based on written, codified legal sources, is widely discussed. The fundamental sources of the Anglo-American legal system are common law, equity and statute law. Common law is often described as judge-made law, which is not based on written codes but on precedents, i.e. decisions of judges taken in previous legal cases. Equity, on the other hand, is a term referring to a system of rules which are applied in addition to common-law and have no equivalent in the continental legal system. Finally, the term statute law applies to written law (e.g. the Acts of Parliament), i.e. those legal sources which exist in written form in the Anglo-American legal system.

Cao (2007: 23) argues that every legal language reflects the history, evolution and culture of the corresponding legal system. More specifically, the style of individual legal languages reflects the corresponding legal culture and logic. De Cruz (1999: 91) states, for example, that the style of German legal texts (the German legal system being one of the main foundations of the continental legal family), reflects the systematic and logical development of German law using an abstract conceptual language, based on highly-abstract, system-oriented, deductive thinking, which is not intended to be comprehensible to the layperson, but is meant to be read by experts who can appreciate "its precision and rigour of thought" (Zweigert 
and Kötz 1992: 150). With regard to the style of legislative drafting, Tetley (2000: 703) defines the style of civil law codes and statutes as concise, while he describes the style of the common law statutes as precise. Furthermore, he argues that the legal English used in common law texts is based on inductive thinking and on an empirical approach to legal problems, which is intended to restrict interpretation possibilities to the minimum.

The discrepancies between common and continental law are reflected in the frequent lack of equivalence between the terms and concepts used in the two legal systems. These discrepancies, which directly result from the gaps existing between these two major legal systems, affect three main terminological areas, ${ }^{4}$ i.e. the terms used to define different types of legal professions, the terminology used to render different court structures and the specific terms referring to particular areas of law and institutions.

In the area of legal professions, the legal professional licensed by the state to advise clients in legal matters and represent them in the court of law, who is called Rechstanwalt in German, avvocato in Italian, odvetnik in Slovene and has a basic role in every continental legal system, has no direct equivalent in the Anglo-Saxon system, as it can be translated as lawyer, counsel, advocate, attorney, solicitor, barrister or counsellor. In the US, lawyers are generally referred to as lawyer and attorney, or more formally as attorney-at-law, and they may all plead cases in the courts of the states in which they are admitted. In the United Kingdom, Canada, Australia and several other common law jurisdictions the lawyers are either barristers (authorized to appear in a superior court, i.e. to argue cases) or solicitors (who generally advise clients and may only appear in an inferior court), while in Scotch law the term used is advocate.

In England, some other Commonwealth countries and former colonies, barristers are further divided into senior and junior

\footnotetext{
${ }^{4}$ Cf. Cao (2007: 60 ff.).
} 
counsels, where senior counsels are barristers appointed to the British crown and, when the sovereign is a woman, they are conferred the title Queen's Counsel (QC).

Another area in which terminological problems occur due to differences in the legal system is the terminological sphere referring to judicial officers. In England and Australia the terms Judge and Justice, as well as Magistrate (for magistrate courts) are used. In Germany and Slovenia, however, there is a distinction between professional judges, who are trained as lawyers and are called Richter in German and sodnik in Slovene, and honorary judges, who are lay judges appointed to assist professional judges and are termed Schöffe in German and porotnik in Slovene and have no functional equivalent in the Anglo-American legal system.

A further important source of translational difficulties is represented by words used to describe the structure and hierarchy of courts. In English common law jurisdiction two words are used to refer to courts: the general term court and a narrower term tribunal, which refers to panels and bodies that exercise administrative or quasi-judicial functions with limited or special jurisdictions, whereas in German and Slovene only one term is used (i.e. Gericht/ sodišče). In England, the court hierarchy comprises the House of Lords as the ultimate appellate court, the Supreme Court of Judicature, the Court of Appeal, the High Court of Justice, the Crown Court, the County Courts and the Magistrates Courts. This structure is hardly comparable with, for instance, the German court hierarchy which includes four hierarchical court levels: das Amtsgericht, das Landesgericht, das Oberlandesgericht and, as the ultimate appellate court, the Bundesgerichtshof. The Slovene court system is similar to the German one (the corresponding courts being okrajno, okrožno, višje and vrhovno sodišče), but as most court systems of continental law countries bears little resemblance to the common law court structure.

The last sphere where the lack of equivalence between the terms 
and concepts of various continental legal systems and those pertaining to common law is strongly felt is represented by the terminology used to define various specialized fields of law and institutions. Within the continental legal family the same major branches of law are found in all countries: constitutional law, administrative law, public international law, criminal law, the law of procedure, civil law, commercial law and labour law. This division is also to be found at lower levels, referring to institutions and concepts. However, if these domains of law and the corresponding institutions are compared to those of the common law legal systems, many conceptual and structural differences are identified. For instance, there are institutions in continental law which are completely foreign to common law, such as cause, abuse of right, the direct action, the oblique action, the extent of strict liability in tort etc. On the other hand, there are common law concepts which do not exist in the continental legal systems, such as consideration or estoppel in contract law, or the notion of privity in different legal contexts. A significant example of a broad and extremely significant concept which is fundamental to continental law, especially to the Romano-Germanic legal systems, but has no equivalent in common law is the law of obligations, which has been developed over the centuries on the basis of Roman law elements. Similarly, a part of the English legal structure, i.e. equity, has no exact counterpart in the continental law, as most of its concepts and legal rules are unique and have no parallels in any other legal system.

Company law is another field where the lack of equivalence between the two systems is strongly felt. The Anglo-American company law does not distinguish between the categories of Kapitalgesellschaften / società di capitali / kapitalske družbe and Personengesellschaften/ società di persone / osebne družbe, but merely between incorporated companies, which have the status of legal persons and unincorporated ones which have no legal personality. 
The terms public limited company and limited liability company can be used relatively safely when translating the company forms Aktiengesellschaft / società per azioni / delniška družba and Gesellschaft mit beschränkter Haftung / Società a responsabilità limitata / družba z omejeno odgovornostjo, but there are no equivalent terms in the English legal terminology for company forms such as Offene Handelsgesellschaft/ società in nome collettivo / družba z neomejeno odgovornostjo or Kommanditgesellschaft / società in accomandita / komanditna družba.

Other cases of non-equivalence derive from the fact that two opposite governance systems are applied in public limited companies, the Anglo-Saxon one-tier and the continental European two-tier systems. Namely, the one-tier system only has one governing body, i.e. the board of directors, whereas in the two-tier system there are two governing bodies, i.e. the management board (Vorstand / consiglio d'amministrazione / uprava) and the supervisory board (Aufsichtsrat / collegio sindacale / nadzorni svet). The terms management board and supervisory board thus do not exist in the Anglo-American legal language and can be classified as neologisms according to de Groot. In practice, the executive (inside) directors have a function similar to the role of the members of the management board in the continental system and the non-executive directors to that of the members of the supervisory board. Similarly, the function of a Prokurist / procuratore commerciale / prokurist (a representative of a company holding a special power-of-attorney, i.e. a procura, authorizing him/her to act on behalf of the company) does not exist in British and American companies and to describe it either the source-language term or a paraphrase has to be used.

The problems deriving from the discrepancy between common law and continental law are also felt within the European Union where English is most often used as lingua franca. ${ }^{5}$ Namely, when

${ }^{5}$ Cf. Kjaer (1999: 72). 
English is used to describe specific aspects and concepts of the European Law or of national legal systems belonging to the continental legal family within the EU, terms are often used, which are tainted by the meaning attributed to them within the AngloAmerican legal system. Such terms, tainted by national law, often cause problems in interpreting international or supranational legal texts. ${ }^{6}$ When for instance the continental concept bona fides is translated into English, most frequently the expression good faith is used, which, however, does not fully render the continental notion. Namely, the English concept of good faith excludes negligence, while the continental understanding of bona fides often regards gross negligence as the equivalent of bad faith. Moreover, the continental concept covers a wider semantic field and includes confidential relationships and a minimal standard of conduct expected of the parties engaging in commercial transaction (Cao 2007: 57-58). Another example of the problems related to the interpretation of terms tainted by the meaning they have within the common law system in international contexts is provided by the "Multilateral International Convention relating to the limitation of the liability of owners of sea-going ships", adopted in Brussels in 1957 (Pallua 1975: $121 \mathrm{ff}$.). When the text of the convention, which had to be drawn up in two equivalent versions in English and French, was discussed by international experts, a major problem was represented by the common law concept of "actual fault or privity". This concept originates from the Merchant Shipping Act from 1894 and has no exact counterpart in continental law. Consequently, the representatives of continental law countries protested that, as the concept could not be adequately translated into French, using this term in the English version would imply the risk of interpreting the concept according to the meaning attributed to it in the Merchant Shipping Act and thus introducing a common law notion into an

\footnotetext{
${ }^{6}$ Cf. de Groot (1992: 283).
} 
international legal text, which was unacceptable. Finally, after extensive discussion the concept was translated into French with the formulation "faute personnelle du proprietaire", whereby the notion of privity was transferred into the semantic field covered by the concept of personal liability. A possible solution for avoiding the risk of using non-equivalent terms in different language versions of a legal documents might be to "terminologize", i.e. to exactly define the meaning of the words / phrases to be used. ${ }^{7}$

Nevertheless, in spite of the problems deriving from its embeddedness in the Anglo-American culture, English will certainly remain the most widely used lingua franca in international communication, as e.g. according to a Eurobarometer survey carried out in 2001, 47\% of the citizens of the EU spoke English well enough to hold a casual conversation, a higher proportion than any other language in Europe. English is also the most commonly taught second language in Europe (Crystal 2002: 16). Due to the language policy of the EU, which promotes the importance of the languages of its member states, other languages will certainly gain ground in the future. On the other hand, although the EU attempts to provide equal treatment for all member state languages, this generally requires large amounts of time and money and therefore the need for a common language that could be used by every member to communicate with everyone else is strongly felt. Due to the United Kingdom's involvement in the EU, Euro-English terms, i.e. English translations of European concepts will have to be adopted by and included into the vocabulary of the native-speakers of English as well. Although most British legal experts who operate in an international environment are familiar with the specific terms referring to concepts originating from continental law (such as the

\footnotetext{
${ }^{7}$ For example, in an agreement/contract initially define the terminology with the following wording: "For the purpose of this Agreement, the following words and phrases shall mean the following:".
} 
notion of bona fides, the specific terminology referring to continental company law, like the function of a Prokurist or the bodies of the two-tier governing system, etc.) and use them in their professional communication, the use of these terms mostly remains limited to the domain of the language for special purposes and is only slowly entering the general vocabulary. An outstanding example of such cultural and linguistic interference was provided by the Prime Minister of the United Kingdom, Tony Blair, in his speech delivered at the European Parliament on 23 June 2005, in which he used the French term delocalization (i.e. companies moving operations abroad), a word that did not previously exist in English. Having been used by a statesman enjoying enormous public attention, the word was immediately adopted by journalists and soon afterwards by the general public and thus entered the official British vocabulary with surprising rapidity.

\section{Conclusion}

With the ongoing harmonization of the legal systems of the EU member states, a sort of supranational language, i.e. legal EuroEnglish, is being created, which includes terms which are neologisms with respect to the Anglo-American legal language. On the other hand, while becoming acquainted with the concepts and terms of this lingua franca, native speakers of English will be able to effectively communicate with other citizens of the EU, expand and enrich their vocabulary and thus adopt new cultural concepts. In the long term it is therefore to be expected that English as a common language used for communication within the EU will contribute to creating a common cultural basis, i.e. elements of a common European culture which will be shared by all its speakers. In the field of legal communication, where English is used as a language for specific purposes, the parties interacting in an international 
environment should be aware that, if linked consistently to the Anglo-American legal system, the English language offers no suitable equivalent for many terms and notions existing in legal systems belonging to the so-called continental legal family and that often, when referring to concepts from continental law, neologisms (such as many Euro-English terms) should be used.

Thus, in legal translation the principle of cultural embeddedness should be applied selectively and by taking into account the possible divergence between the communication language(s) and the legal system as communication framework. Therefore, when translating (culturally transferring) legal concepts, two guidelines have to be followed, i.e. safeguarding the legal security of the target text and ensuring the transparency of the translational decisions. This, however, requires the translator to be well acquainted with the legal systems of both the source and the target culture and to thus act not only as an intercultural, but also interdisciplinary expert. Finally, by translating and transferring legal concepts across cultures another process takes place, which has been identified and described by the translation scientist Andrew Chesterman. Chesterman defines translations as "survival machines for memes" (Chesterman 1997: 5 ff.). In this connection he uses the term meme, which originates from socio-biology and has been introduced by Dawkins in his work The Selfish Gene (1976), as the equivalent for " $a$ unit of cultural transmission" (Chesterman 1997: 5). Accordingly, memes are to be understood as entities encapsulating ideas, concepts, beliefs, etc., which can only be transmitted verbally across cultures by means of translation. Chesterman views translation not merely as a transfer, but more as spreading, propagation, diffusion, even evolution of memes, i.e. as a process that definitely affects not only the source and target language, but also the corresponding cultures. By transmitting memes through replication, spreading and even interpreting of new concepts and ideas, translation procedures modify and enrich the languages and cultures involved in the translation 
process. Consequently, legal translation could contribute to spreading and deepening the knowledge about different legal systems, raising the awareness as to their common features and differences, as well as to creating a base of the most significant memes representing the foundations of the different legal systems and corresponding languages.

\section{References}

Bassnett, S. 1991. Translation Studies: Revised Edition. London \& New York: Routledge.

Cao, D. 2007. Translating Law. Clevedon: Multilingual Matters.

Chesterman, A. 1997. Memes of Translation. Amsterdam \& Philadelphia: John Benjamins.

Crystal, D. 1997. English as a Global Language. Cambridge: CUP. . 2002. English in the New World. Babylonia 1.2, 16-17.

Dawkins, R. 1976. The Selfish Gene. Oxford: Oxford University Press.

De Cruz, P. 1999. Comparative Law in a Changing World. London: Cavendish Publishing.

Essen, A. 2002. English is not English. Babylonia 1.2, 10-15.

Groot de, G-R. 1992. Recht, Rechtssprache und Rechtssystem. Betrachtungen über die Problematik der Übersetzung Juristischer Texte. In Office des Publications Officielles des Communautés Européennes: Terminologie et Traduction 279316. Bruxelles \& Luxembourg: Commission des Comm. . 1998. Language and Law. In Netherlands Reports to the Fifteenth International Congress of Comparative Law 21-32. Antwerp \& Groningen: Intersentia.

Jenkins, I. 1980. Social Order and the Limits of Law: A Theoretical Essay. New York: Princeton University Press.

Jenkins, J. \& B. Seidlhofer. 2001. Be Proud of Your Lingua Franca. 
70 The Cultural Embeddedness of Legal Texts

The Guardian Weekly April 19.

Kjær, A. 1999. Überlegungen zum Verhältnis von Sprache und Recht bei der Übersetzung von Rechtstexten der Europäischen Union. In P. Sandrin (ed.), Übersetzen von Rechtstexten: Fachkommunikation im Spannungsfeld zwischen Rechtsordnung und Sprache I: 63-79. Tübingen: Narr.

Labrie, N. \& C. Quell. 1997. Your Language, My Language or English? The Potential Language Choice in Communication among Nationals of the European Union. World Englishes 16.1, 3-26.

Nord, C. 1997. Translating as a Purposeful Activity: Functionalist Approaches Explained. Manchester: St. Jerome.

Pallua, E. 1975. Pomorsko uporedno pravo. Rijeka: Viša pomorska škola.

Reiß, K. \& H. Vermeer. 1984. Grundlegung einer Allgemeinen Translationstheorie. Tübingen: Niemeyer.

Sandrini, P. 1999. Translation zwischen Kultur und Kommunikation:

Der Sonderfall Recht. In P. Sandrini (ed.), Übersetzen von Rechtstexten. Fachkommunikation im Spannungsfeld zwischen Rechtsordnung und Sprache 9-43. Tübingen: Narr.

Sapir, E. 1931. The Function of an International Auxiliary Language. In H. Shenton, E. Sapir \& O. Jespersen (eds.), International Communication 65-94. London: Kegan Paul.

Tetley, W. 2000. Mixed Jurisdictions: Common Law vs Civil Law (Codified and Uncodified). Louisiana Law Review 60, 677-738. Vermeer, H. 1987. What Does It Mean to Translate? Indian Journal of Applied Lingustics 13.2, 25-33.

Zweigert, K. \& Kötz, H. 1992. An Introduction to Comparative Law. Oxford: Clarendon Press. 